Research Article

Open Access

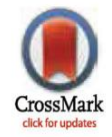

Department of Science Technology, Akwa Ibom State Polytechnic, Ikot Osurua, P.M.B 1200, Ikot Ekpene, Akwa Ibom State, Nigeria.

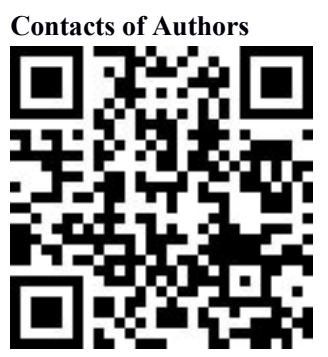

To whom correspondence should be addressed: Aniefon Alphonsus Ibuot

Citation: James II, Ben MG, Jones AM, Akpan PS, Eka II, Oruk AE, Ibuot AA (2020). Characterization of hydrocarbon utilizing bacteria in waste engine oil-impacted sites. Highlights in BioScience Volume 3. Article ID 20218. dio:10.36462/H.BioSci.20218

Received: June 6, 2020

Accepted: August 18, 2020

Published: August 31, 2020

Copyright: (C) 2020 James et al. This is an open access article distributed under the terms of the Creative Commons Attribution License, which permits unrestricted use, distribution, and reproduction in any medium, provided the original author and source are credited.

Data Availability Statement: All relevant data are within the paper and supplementary materials.

Funding: The authors have no support or funding to report.

Competing interests: The authors declare that they have no competing interests.

\section{Characterization of hydrocarbon utilizing bacteria in waste engine oil-impacted sites}

\author{
Iniobong Ime James, Mayen Godwin Ben, Agnes Monday Jones,Patience \\ Saturday Akpan, Idorenyin Idorenyin Eka, Albert Ema Oruk, and Aniefon \\ Alphonsus Ibuot*
}

\section{Abstract}

Changes in soil physicochemical properties and bacterial species present in soil contaminated with waste engine oil were evaluated at three auto-mechanical workshops in Uyo, Nigeria. This work was aimed at isolating and identifying hydrocarbon degrading bacteria from waste engine oil polluted soil, and assessing their hydrocarbon-utilizing ability. Waste engine oil pollution affected soils significantly with increases in soil physicochemical properties, and heterotrophic bacterial population counts. Eight bacterial species Corynebacterium kutscheri, Pseudomonas aeruginosa, Flavobacterium aquatile, Serratia odorifera, Micrococcus agilis, Staphylococcus aureus, Micrococcus luteus and Bacillus substilis were isolated by the selective enrichment technique and screened for hydrocarbon utilization capability in mineral salt media with $1 \%(\mathrm{v} / \mathrm{v})$ waste engine oil as a sole carbon and energy source. The extent of bacterial growth observed was related to the ability of organisms to biodegrade hydrocarbons present in the medium bacterium species, which showed varying hydrocarbon utilization during the 15 days of incubation. Growth in hydrocarbon medium was the most efficient in cultures of Corynebacterium kutscheri. All isolates also showed variable emulsification ability, with Corynebacterium kutscheri, showing the highest ability. These results demonstrate the presence of indigenous bacteria in hydrocarbon-polluted soils and the potential toward the remediation of hydrocarbons.

Keywords: Hydrocarbon-utilizing bacteria, selective enrichment technique, Corynebacterium kutscheri

\section{Introduction}

Petroleum utilization as fuel and petroleum products leads to severe environmental pollution [1]. Large-scale accidental spills pose a great threat to the ecosystem [2]. Soil pollution by petroleum hydrocarbons has been shown to produce pronounced changes in the physicochemical and microstructure of the oil-contaminated soil [3]. This affects parameters such as soil porosity, bulk density, and adsorption [4-5]. Fresh spills and/or high levels of pollutants may often result in the reduction of large sectors of soil microbial population, although soils with lower levels or old pollution may show an increase in numbers and diversity of microorganisms [6-7]. The diversity and the number of microorganisms at polluted soil sites may assist in the characterization of such a site, such as the toxicity of petroleum hydrocarbons to the microbiome, age of the spill and concentration of the pollutant [8]. 
Additionally, microorganisms in soils exposed to hydrocarbon pollution usually exhibit a higher potential for biodegradation of such pollutant compounds than others with no history of such exposure. Percentages of hydrocarbonoclastic microbes are quite low in soil when there is no oil spill, but may increase 1,000 fold after oil spill [9].

Conventional remediation methods do not seem to be able to address this problem, or tends to aggravate the problem [10]. Mechanical methods such as incineration, excavation and/or burial in secure land fill, as well as a host of other chemical decomprelocates osition methods are expensive, time consuming and only the pollution [11]. An efficient way of remediating the oil-contaminated sites could be employment of microorganisms, such as bacteria, microscopic algae, and fungi, isolated from polluted environments or enhanced from the organisms already present in the same environment [12-13]. Waste engine oil-polluted soils also serve as a source of indigenous bacteria capable of hydrocarbon degradation.

The employment of microorganisms in the biodegradation of hydrocarbons over chemical or conventional treatment is preferred for many reasons; end products are comparatively safer and cost-effectiveness [11]. Ogunbayo et al., [18] evaluated the effectiveness of bacteria indigenous to soil in remediating engine oil-polluted, soil and isolated Bacillus, Pseudomonas, Flavobacterium, Micrococcus and Rhodococcus species, with Pseudomonas and Rhodococcus species giving most favorable degradation effectiveness and efficiencies.

This study therefore considered the isolation of indigenous bacterial communities in waste engine oil-polluted soil using selective enrichment technique, and the assessment of hydrocarbon-utilization capability in waste engine oil-augmented mineral salt medium.

\section{Materials and Methods}

\section{Sample collection}

Waste engine oil -contaminated soil samples used in this study were collected from three auto-mechanic workshops within the mechanic village, Uyo, Akwa Ibom State, Nigeria. Composite soil samples were obtained at each sampling point using a soil auger from $0-10 \mathrm{~cm}$ below the soil surface. The soils were labeled "Unpolluted" for the unpolluted sample, "MA" for the mechanic workshop 1 sample, "MB" for the mechanic workshop 2 samples, and "MC" for the mechanic workshop 3 samples. This was followed by bulking and transportation to the laboratory in sterile polythene bags within six hours for isolation of organisms.

\section{Physico-chemical analysis of soil samples}

The soil $\mathrm{pH}$ was measured using HANNA Instruments Model $209 \mathrm{pH}$ meter [14]. Moisture content was calculated on the basis of the air dry weight as described by AOAC [15]. Total organic carbon was calculated by weighing exactly $0.5 \mathrm{~g}$ of the soil sample into a flask, and 10 $\mathrm{ml}$ of $1.0 \mathrm{M} \mathrm{K}_{2} \mathrm{Cr}_{2} \mathrm{O}_{7}$ was added and swirled to mix. $20 \mathrm{ml}$ conc. $\mathrm{H}_{2} \mathrm{SO}_{4}$ was added, gently swirled for a minute and allowed to stand for 20 minutes. The suspension was diluted to about $100 \mathrm{ml}$ of distilled water. Five drops of o-phenanthroline indicator were added to each sample and was titrated with $0.5 \mathrm{M}$ ferrous ammonium sulfate to a light blue end point. The reagent blank was also run and the titre values recorded, and used to calculate the organic carbon content [15].

The total hydrocarbon content (THC) was determined by first extracting hydrocarbons by acidifying $2 \mathrm{~g}$ of representative soil samples using $\mathrm{H}_{2} \mathrm{SO}_{4}$, and extracting upon addition of $20 \mathrm{ml}$ of toluene in a separatory funnel. The contents of the funnel were shaken, and allowed to settle into two layers. The absorbance of the supernatant (extract) was read at $420 \mathrm{~nm}$ with UNICAM UV/VIS spectrophotometer (Spectronic 20D). Readings were recorded from the spectrophotometer and using the determined curve to obtain the figure [16].

Phosphorus was determined using the ascorbic acid method as described by AOAC, [15]. $50 \mathrm{ml}$ of the soil dilution was pipetted into $250 \mathrm{ml}$ Erlenmeyer flask, and 1 drop of phenolphthalein indicator was added. Exactly $5 \mathrm{~N}$ $\mathrm{H}_{2} \mathrm{SO}_{4}\left(148 \mathrm{ml}\right.$ conc. $\mathrm{H}_{2} \mathrm{SO}_{4}$ in $\left.100 \mathrm{ml} \mathrm{H}_{2} 0\right)$ is added drop-wise to develop a red colour. Exactly $8 \mathrm{ml}$ of combined reagents made up of $50 \mathrm{ml}$ of $5 \mathrm{~N} \mathrm{H}_{2} \mathrm{SO}_{4}, 5 \mathrm{ml}$ potassium antimonyl tartrate solution (1.372 $\mathrm{g}$ potassium antimonyl tartrate in $500 \mathrm{ml}$ distilled water); $15 \mathrm{ml}$ ammonium molybdate solution (20 g ammonium molybdate crystal in $500 \mathrm{ml}$ distilled water); were added and thoroughly mixed, and allowed to stand for $20 \mathrm{~min}$. The phosphorus content was determined by measuring the absorbance of the sample at $880 \mathrm{~nm}$.

The nitrogen concentration was determined according to the methods of Bremmer and Mulvaney, [17]. One milliliter of the soil sample was introduced into the standard kjeldahl flask containing $1.5 \mathrm{~g} \mathrm{CuSO}_{4}$, and $1.5 \mathrm{~g} \mathrm{Na}_{2} \mathrm{SO}_{4}$ as catalyst, alongside concentrated $\mathrm{H}_{2} \mathrm{SO}_{4}$. The flask was gently heated on a heating mantle, taking care to prevent frothing. The solution was transferred after heating to a $100 \mathrm{ml}$ standard flask and made up to the mark with distilled water. A portion of this digest was pipetted into a semi micro-kjeldahl distillation apparatus and treated with $30 \mathrm{ml}$ of $40 \% \mathrm{NaOH}$ solution. The ammonia evolved was steam-distilled into a $100 \mathrm{ml}$ conical flask containing $10 \mathrm{ml}$ solution of saturated boric acid to which 4 drops of Tashirus indicator had been previously added. The tip of the condenser was immersed in the boric acid solution and the distillation continued until about two-thirds of the original volume was obtained. The tip of the condenser was finally rinsed with a few milliliters of distilled water. The distillate was then titrated with $0.1 \mathrm{~N} \mathrm{HCl}$ until a purple-pink end point was observed. A blank determination was also carried out in a similar manner without the sample, and the calculation done as follows:

$$
\text { Nitrogen }(\%)=\frac{(\text { Real titre }- \text { Blank titre })}{\text { Weight of the sample }} \times 0.1 \times 0.014 \times 100
$$

\section{Enumeration of total heterotrophic bacteria (THB)}

The THB population in the soil samples was enumerated by adopting the standard plate counts technique using the spread plate method as described by Ogunbayo et al., [18]. These involved spreading aliquots of a serially 
diluted $0.1 \mathrm{ml}$ of $10^{-5}$ dilutions of the soil sample suspension on nutrient agar plates and the plates were incubated at $30^{\circ} \mathrm{C}$ for $24 \mathrm{~h}$. Similar aliquots were also incubated in minimal salt agar plates containing used engine oil as the sole source of carbon and energy. The plates were all incubated aerobically at $30{ }^{\circ} \mathrm{C}$. The percentages of hydrocarbon-utilizing bacteria (HUB) relative to the total heterotrophic counts were noted.

\section{Enumeration of hydrocarbon utilizing bacteria (HUB)}

Oil-utilizing bacteria were isolated from polluted soil samples by enrichment in mineral salt medium (MSM) modified from Okpokwasili and Nwosu, [19] using waste engine oil as a carbon and energy source. The soil samples were sieved using a $2 \mathrm{~mm}$ mesh sieve. $10 \mathrm{~g}$ of the sieved soil samples was inoculated into $100 \mathrm{ml}$ sterile MSM. $1 \mathrm{ml}$ of the waste engine oil was added to the medium as a sole source of carbon and energy, and the culture was incubated on a rotary shaker at $170 \mathrm{rpm}$ for 1 week.

The enrichment procedure was repeated for three cycles. At the end of each enrichment cycle, $1 \mathrm{ml}$ of the culture was diluted serially 10 -fold down the gradient to $10^{-5}$ and plated. Pure cultures of the isolates were obtained by plating $1 \mathrm{ml}$ of the $10^{-5}$ dilution of the third enrichment cycle onto MSM agar plates, and incubating at $30{ }^{\circ} \mathrm{C}( \pm 2)$ for $48 \mathrm{~h}$. Pure cultures obtained by this procedure were stored in slants at 4 ${ }^{\circ} \mathrm{C}$ until further identification.

\section{Characterization and identification of bacteria}

Isolates were identified on the basis of colonial characteristics, Gram's reaction and cell biochemical reactions as described by Cheesbrough [20]. Identification used the taxonomic schemes of Holt et al. [21].

\section{Hydrocarbon utilization screening of bacteria}

To determine the ability of the isolates to utilize engine oil as the sole carbon and energy source, the growth patterns of isolates in mineral salt medium in the presence of $1 \%(\mathrm{v} / \mathrm{v})$ of the waste engine oil $(5.0 \mathrm{~mL}$ in $100 \mathrm{~mL}$ MSM) were determined according to Onuoha et al. [22]. Waste engine oil-augmented MSM was dispensed into $250 \mathrm{ml}$ Erlenmeyer, and inoculated with $0.1 \mathrm{ml}$ of $24 \mathrm{~h}$ cultures of the bacterial isolates. Incubation was done at $30{ }^{\circ} \mathrm{C}$ for 15 days. Growth patterns were determined monitoring changes in $\mathrm{pH}$, optical density and total viable count at 5-day intervals during the incubation. The $\mathrm{pH}$ of the medium was measured using the pH meter (HANNA Instruments). Growth was also monitored by measuring the optical density (OD) at $600 \mathrm{~nm}$ using the spectrophotometer (Spectrumlab). Total viable counts of the cultures were obtained by incubation of $0.1 \mathrm{ml}$ of the cultures using the spread plate technique on nutrient agar plates at $30{ }^{\circ} \mathrm{C}$ for $24 \mathrm{~h}$.

\section{Emulsification activity of bacteria}

The emulsification index $\left(\mathrm{E}_{24}\right)$ of the isolates was determined according to the methods of Ganesh and Lin, [23], by adding $1 \mathrm{ml}$ of waste engine oil to the same amount of culture media as used for degradation assay, mixing the vortex for $2 \mathrm{~min}$ and leaving to stand for $24 \mathrm{~h}$. The percentage of emulsification index was obtained as follows:

$$
\mathrm{E}_{24}=\frac{\text { Height of the emulsified layer }}{\text { Total height of the liquid column }} \times 100
$$

\section{Results}

\section{Physicochemical properties of soil samples}

The results of the physicochemical analysis of the different soil sample are shown in Table 1. The high amounts of organic carbon $(5.32 \pm 2.65 \%$ in MA, $9.79 \pm$ $0.51 \%$ in MB and $7.29 \pm 3.09 \%$ in MC), and THC (2933.76 \pm $404.27 \mathrm{mg} / \mathrm{kg}$ in MA, $3122.72 \pm 131.00 \mathrm{mg} / \mathrm{kg}$ in MB and $3202.61 \pm 675.07 \mathrm{mg} / \mathrm{kg}$ in $\mathrm{MC})$, compared to the unpolluted soil sample $(3.7 \pm 2.43 \%$ organic carbon content and $39.97 \pm$ $13.49 \mathrm{mg} / \mathrm{kg}$ THC) is indicative of heavy pollution of the mechanical workshop samples with petroleum hydrocarbons. Soil samples from mechanical workshop 1 contained higher amounts of nitrates $(0.25 \pm 0.03 \mathrm{mg} / \mathrm{g})$, while samples from mechanical workshop 2 contained the highest amounts of phosphates $(10.74 \pm 0.88 \mathrm{mg} / \mathrm{g})$ and THC (3202.61 \pm 675.07 $\mathrm{mg} / \mathrm{kg}$ ). The $\mathrm{pH}$ values of the soil samples indicate all soil samples as moderately acidic to acidic (from $\mathrm{pH} 5.78$ to $\mathrm{pH}$ 6.79).

\section{Bacterial count of soil samples}

The total heterotrophic bacterial count and hydrocarbon utilizing bacterial count of the original soil samples is shown in Table 2. A higher THB count was recorded in polluted soil samples $\left(4.4 \pm 1.90 \times 10^{7} \mathrm{CFU} / \mathrm{g}\right.$ from MA sample, $6.0 \pm 0.23$ $\mathrm{x} 10^{7} \mathrm{CFU} / \mathrm{g}$ from MB sample and $4.5 \pm 0.03 \times 10^{7} \mathrm{CFU} / \mathrm{g}$ from $\mathrm{MC}$ sample) than in the unpolluted soil sample $(1.9 \mathrm{x}$ $\left.10^{7} \mathrm{CFU} / \mathrm{g}\right)$. Higher THB $\left(6.0 \pm 0.23 \times 10^{7} \mathrm{CFU} / \mathrm{g}\right)$ and HUB $\left(5.2 \pm 0.25 \times 10^{7} \mathrm{CFU} / \mathrm{g}\right)$ counts were observed in the MB sample than in other similar polluted samples indicative of its extent of pollution. Hydrocarbon utilising bacterial counts were slightly lower in all samples than the corresponding heterotrophic bacterial counts.

\section{Characterization and identification of bacteria}

The identified bacterial isolates were Corynebacterium kutscheri, Pseudomonas aeruginosa, Micrococcus agilis, Flavobacterium aquatile, Staphylococcus aureus, Micrococcus luteus, Serratia odorifera and Bacillus substilis, as shown in Table 3 and 4.

\section{Hydrocarbon utilization potential of bacteria}

Table 5 shows the changes in $\mathrm{pH}$ of MSM during growth of bacteria isolates in hydrocarbon. Decreases in $\mathrm{pH}$ (to $<\mathrm{pH}$ 7.00) were observed in medium containing isolates, Corynebacterium kutscheri, Micrococcus agilis, Serratia odorifera and Bacillus substilis, (which, however, increased to above $\mathrm{pH} 7.00$ ). The greatest decrease in $\mathrm{pH}$ occurred in cultures of Corynebacterium kutscheri (from 7.00 a.m. on Day 0 to $5.83 \pm 0.34$ on Day 15). Medium containing other isolates showed slight increases in $\mathrm{pH}$ over time. The changes in the total viable counts of bacterial isolates during 15 days of growth in waste engine oil-augmented MSM are shown in Table 6. Total viable counts were higher in cultures containing Corynebacterium kutscheri $\left(1.94 \pm 0.12 \times 10^{8}\right.$ $\mathrm{CFU} / \mathrm{ml}$ on Day $5,6.73 \pm 0.45 \times 10^{8} \mathrm{CFU} / \mathrm{ml}$ on Day 10 and $3.13 \pm 0.02 \times 10^{8}$ on Day 15). Growth of Staphylococcus aureus showed the lowest decreases $\left(0.31 \pm 0.11 \times 10^{8}\right.$ on Day 
$5,0.44 \pm 0.01 \times 10^{8}$ on Day 10 and $0.42 \pm 0.02 \times 10^{8}$ on Day 15).

Table 7 shows the results of turbidity measurement $\left(\mathrm{OD}_{600}\right)$ of the medium during incubation. The highest increases in turbidity were recorded in cultures with Corynebacterium kutscheri, $(0.189 \pm 0.04$ on Day 0 to $0.301 \pm 0.11$ on Day 15), and Bacillus substilis, $(0.165 \pm 0.04$ on Day 0 to $0.341 \pm 0.02$ on Day 15$)$. The lowest turbidity was observed with Staphylococcus aureus $(0.20 \pm 0.04$ on Day 0 to $0.14 \pm 0.02$ on Day 15).

\section{Emulsification activity of bacteria}

Figure 1 shows the emulsification index $\left(E_{24}\right)$ of the bacterial isolates in waste engine oil. Corynebacterium kutscheri had the highest emulsification index (52\%). The lowest emulsification index was observed for Staphylococcus aureus (8\%).

Table 1: Physicochemical properties of different soil samples contaminated with waste engine oil.

\begin{tabular}{l|llc}
\hline \multirow{2}{*}{ Parameters } & Unpolluted (Control) & \multicolumn{2}{c}{ Polluted } \\
\cline { 3 - 4 } & & MA & MB \\
\hline pH & $6.79 \pm 0.24$ & $6.18 \pm 0.13$ & $5.78 \pm 0.03$ \\
Nitrate (mg/g) & $0.14 \pm 0.02$ & $0.25 \pm 0.03$ & $0.23 \pm 0.02$ \\
Phosphate (mg/g) & $6.65 \pm 1.72$ & $6.92 \pm 2.92$ & $10.74 \pm 0.88$ \\
Moisture content (\%) & $32.25 \pm 9.30$ & $43.09 \pm 0.65$ & $45.13 \pm 7.02$ \\
Organic carbon content (\%) & $3.7 \pm 2.43$ & $5.32 \pm 2.65$ & $9.79 \pm 0.51$ \\
THC (mg/kg) & $39.97 \pm 13.49$ & $2933.76 \pm 404.27$ & $27.72 \pm 9.09$ \\
\hline Values & & $3202.61 \pm 675.07$ \\
\hline
\end{tabular}

Values represent means of triplicate determinations \pm SD. MA $=$ Mechanic Workshop 1, MB $=$ Mechanic Workshop 2, MC $=$ Mechanic Workshop 3. THC $=$ Total hydrocarbon content.

Table 2: Bacterial count of soil samples contaminated with waste engine oil.

\begin{tabular}{|c|c|c|c|c|}
\hline \multirow{2}{*}{ Parameter } & \multirow{2}{*}{ Unpolluted (Control) } & \multicolumn{3}{|c|}{ Polluted } \\
\hline & & MA & MB & MC \\
\hline THB (CFU/g) & $1.9 \pm 0.02 \times 107$ & $4.4 \pm 1.90 \times 107$ & $6.0 \pm 0.23 \times 107$ & $4.5 \pm 0.03 \times 107$ \\
\hline HUB (CFU/g) & $6.5 \pm 0.04 \times 106$ & $3.2 \pm 0.05 \times 107$ & $5.2 \pm 0.25 \times 107$ & $1.9 \pm 0.10 \times 106$ \\
\hline
\end{tabular}

Values represent means of triplicate determinations \pm SD. MA = Mechanic Workshop 1, MB= Mechanic Workshop 2, MC $=$ Mechanic Workshop 3.

Table 3 : Biochemical characteristics of spore (Sp), catalase (Ca), motility (Mo), oxidase (Ox), litmus reaction (Lr), urease (Ur), gelatin (Ge), citrate (Ci), glucose (Gl), maltose (Mal), mannitol (Man), lactose (La), sucrose (Su), arabinose (Ar) and xylose (Xy) for studied bacterial isolates from soil contaminated with waste engine oil.

\begin{tabular}{|c|c|c|c|c|c|c|c|c|c|c|c|c|c|c|c|c|}
\hline Isolates & Isolate code & Sp & $\mathbf{C a}$ & Mo & $\mathbf{O x}$ & Lr & $\mathbf{U r}$ & Ge & $\mathbf{C i}$ & Gl & Mal & Man & $\mathbf{L a}$ & Su & Ar & $\mathbf{X y}$ \\
\hline 1 & MA3, MB1, MC4 & - & + & - & - & - & - & - & + & A & A & A & - & - & - & $\mathrm{AG}$ \\
\hline 2 & MA2, MB2 & - & + & + & + & + & - & + & - & - & $\mathrm{A}$ & $\mathrm{A}$ & A & - & $\mathrm{A}$ & $\mathrm{A}$ \\
\hline 3 & MA1 & - & + & - & - & - & - & - & - & A & - & A & - & - & $\mathrm{AG}$ & $\mathrm{AG}$ \\
\hline 4 & MA4 & - & + & - & + & + & - & - & - & A & A & - & A & A & - & - \\
\hline 5 & MB3, MC1, MC2, MA5 & - & + & - & - & + & - & - & - & - & - & - & - & A & - & - \\
\hline 6 & MA6 & - & + & - & + & - & - & - & - & - & - & A & - & A & - & - \\
\hline 7 & $\mathrm{MC} 3$ & - & + & + & - & - & + & + & + & A & A & A & A & A & A & - \\
\hline 8 & MB4, MC5 & + & + & + & - & + & - & + & + & A & A & A & - & A & A & $\mathrm{AG}$ \\
\hline
\end{tabular}

Keys: $\mathrm{AG}=$ acid and gas production; $\mathrm{A}=$ acid production only; $+=$ positive reaction; - = negative.

Table 4: Phenotypic characteristics of bacterial isolates from soil contaminated with waste engine oil.

\begin{tabular}{l|lll}
\hline Isolates & Isolate code & Gram reaction/Cell shape & Probable Bacteria \\
\hline $\mathbf{1}$ & MA3, MB1, MC4 & Gram-positive Rods & Corynebacterium kurtscheri \\
$\mathbf{2}$ & MA2, MB2 & Gram-negative Rods & Pseudomonas aeruginosa \\
$\mathbf{3}$ & MA1 & Gram-positive Cocci & Micrococcus agilis \\
$\mathbf{4}$ & MA4 & Gram-negative Rods & Flavobacterium aquatile \\
$\mathbf{5}$ & MB3, MC1, MC2, MA5 & Gram-positive Cocci & Staphylococcus aureus \\
$\mathbf{6}$ & MA6 & Gram-positive Cocci & Micrococcus luteus \\
$\mathbf{7}$ & MC3 & Gram-negative Rods & Serratia odorifera \\
$\mathbf{8}$ & MB4, MC5 & Gram-positive Rods & Bacillus substilis \\
\hline
\end{tabular}


Table $5: \mathrm{pH}$ of the medium during the growth of bacterial isolates in hydrocarbon medium.

\begin{tabular}{l|lll}
\hline \multirow{2}{*}{ Isolates } & \multicolumn{3}{c}{ Days } \\
\cline { 2 - 4 } & $\mathbf{0}$ & $\mathbf{5}$ & $\mathbf{1 0}$ \\
\hline Micrococcus agilis & 7.00 & $6.51 \pm 0.01$ & $6.38 \pm 0.03$ \\
Pseudomonas aeruginosa & 7.00 & $7.06 \pm 0.07$ & $7.78 \pm 0.01$ \\
Corynebacterium kutscheri & 7.00 & $6.51 \pm 0.01$ & $6.38 \pm 0.00$ \\
Flavobacterium aquatile & 7.00 & $7.31 \pm 0.23$ & $7.50 \pm 0.16$ \\
Micrococcus luteus & 7.00 & $6.13 \pm 0.07$ & $7.23 \pm 0.03$ \\
Staphylococcus aureus & 7.00 & $7.23 \pm 0.03$ & $7.31 \pm 0.03$ \\
Serratia odorifera & 7.00 & $7.09 \pm 0.01$ & $6.73 \pm 0.04$ \\
Bacillus substilis & 7.00 & $6.85 \pm 0.13$ & $6.78 \pm 0.18$ \\
\hline Data represent
\end{tabular}

Data represent means of triplicate determinations \pm SD.

Table 6: Total viable count (TVC) of bacterial isolates during growth in hydrocarbon medium (x 108 CFU/ml).

\begin{tabular}{l|llll}
\hline \multirow{2}{*}{ Isolates } & \multicolumn{3}{c}{ Days } & $\mathbf{1 5}$ \\
\cline { 2 - 5 } & $\mathbf{0}$ & $\mathbf{5}$ & $\mathbf{1 0}$ & $0.87 \pm 0.06$ \\
\hline Micrococcus agilis & 0 & $0.63 \pm 0.03$ & $2.46 \pm 0.02$ & $0.45 \pm 0.02$ \\
Pseudomonas aeruginosa & 0 & $0.54 \pm 0.02$ & $2.13 \pm 0.16$ & $3.18 \pm 0.07$ \\
Corynebacterium kutscheri & 0 & $1.94 \pm 0.08$ & $5.27 \pm 0.07$ & $1.43 \pm 0.03$ \\
Micrococcus luteus & 0 & $0.95 \pm 0.01$ & $2.49 \pm 0.03$ & $3.13 \pm 0.02$ \\
Flavobacterium aquatile & 0 & $1.94 \pm 0.12$ & $6.73 \pm 0.45$ & $0.42 \pm 0.02$ \\
Staphylococcus aureus & 0 & $0.31 \pm 0.11$ & $0.44 \pm 0.01$ & $0.48 \pm 0.04$ \\
Serratia odorifera & 0 & $0.54 \pm 0.03$ & $2.23 \pm 0.25$ & $2.47 \pm 0.07$ \\
Bacillus substilis & 0 & $1.39 \pm 0.41$ & $4.08 \pm 0.65$ & \\
\hline
\end{tabular}

Data represent means of triplicate determinations \pm SD.

Table 7: Turbidity measurement of bacterial growth in hydrocarbon medium (OD600).

\begin{tabular}{l|lll}
\hline \multirow{2}{*}{ Isolates } & \multicolumn{3}{c}{ Hours } \\
\cline { 2 - 5 } & $\mathbf{0}$ & $\mathbf{5}$ & $\mathbf{1 0}$ \\
\hline Microccoccus agilis & $0.97 \pm 0.01$ & $0.154 \pm 0.01$ & $0.209 \pm 0.12$ \\
Pseudomonas aeruginosa & $0.033 \pm 0.001$ & $0.035 \pm 0.10$ & $0.182 \pm 0.10$ \\
Corynebacterium kutscheri & $0.189 \pm 0.04$ & $0.252 \pm 0.07$ & $0.386 \pm 0.04$ \\
Flavobacterium aquatile & $0.085 \pm 0.01$ & $0.153 \pm 0.08$ & $0.196 \pm 0.07$ \\
Micrococcus luteus & $0.040 \pm 0.02$ & $0.083 \pm 0.06$ & $0.162 \pm 0.03$ \\
Staphylococcus aureus & $0.20 \pm 0.04$ & $0.053 \pm 0.10$ & $0.084 \pm 0.05$ \\
Serratia odorifera & $0.40 \pm 0.02$ & $0.172 \pm 0.11$ & $0.121 \pm 0.001$ \\
Bacillus substilis & $0.165 \pm 0.05$ & $0.204 \pm 0.01$ & $0.413 \pm 0.05$
\end{tabular}

Data represent means of triplicate determinations $\pm \mathrm{SD}$.

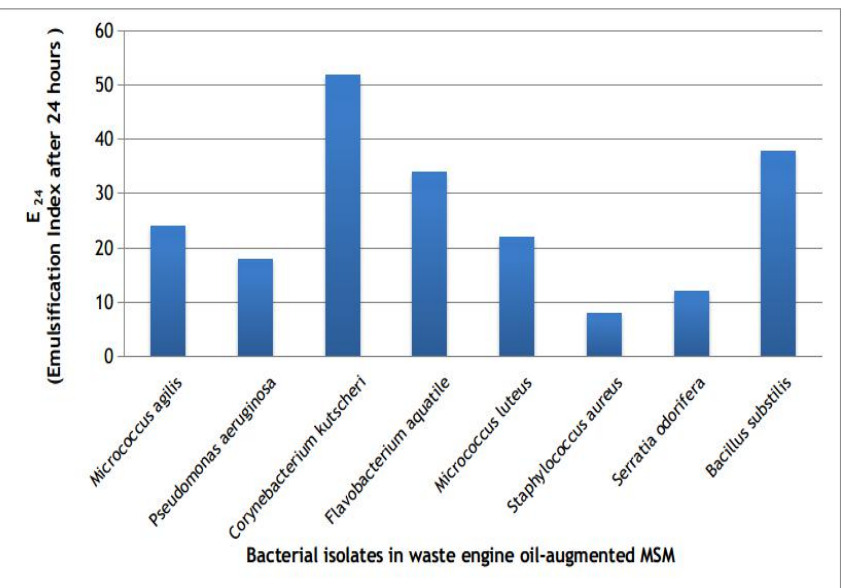

Figure 1 : Emulsification activity (E24) of bacterial isolates.

\section{Discussion}

This study on the assessment of hydrocarbon utilizing the potential of bacteria isolated from waste engine oil-polluted soil on hydrocarbons reveals the presence of hydrocarbon-utilizing bacteria in waste engine oil-polluted soil environment as well as the potential of one of these isolates Corynebacterium kutscheri to degrade hydrocarbons under a variety of experimental conditions.
The results of the physicochemical analysis of the soil samples, as presented in Table 1 showed higher levels of properties in the polluted soil samples when compared with the unpolluted soil sample. The results support the results of Chikere [24], and Chikere and Ekwuabu [25], which showed high physicochemical parameters in polluted soil samples compared to unpolluted samples determined and indicated previous exposure of polluted samples to hydrocarbon contamination with traces of other organic and inorganic contaminants.

The high bacterial counts recorded in polluted soil samples, as presented in Table 2, compared with the unpolluted control samples could be attributed to the myriad of nutrients, high organic matter concentration and other ecological factors that influence the survival of soil microorganisms that play important roles in the decomposition and recycling of nutrients [26]. Luepromchai et al. [27] has reported an increase in the numbers of hydrocarbon degraders in soil in the presence of PAHs, without any impact on the overall bacterial numbers. The difference between THB and HUB counts was observed to be minimally insignificant, which suggests that most of the micro-organisms present in various polluted sample sites are 
hydrocarbon degraders that can withstand the concentrations of hydrocarbons and use them as a source of carbon [25].

The investigation of the morphology and type of bacterial colonies obtained from the oil-polluted soil showed seven bacterial species, which are Corynebacterium kutscheri, Pseudomonas aeruginosa, Micrococcus agilis, Flavobacterium aquatile, Staphylococcus aureus, Micrococcus luteus, Serratia odorifera, and Bacillus substilis. This shows the majority of bacteria isolated as being Gram-positive species. Some researchers have, however, reported oil-polluted soils as being dominated by Gram-negative bacteria [25]

The results of the emulsification test as shown in Figure 1 demonstrates that the isolates produced emulsifying compounds. A large variety and number of biosurfactant producers have been isolated from hydrocarbon-impacted sites [28], although they have also been identified from soils, which are unconnected to hydrocarbon contamination [29]. Corynebacterium kutscheri showed the highest emulsification (52\%) at $1 \%$ waste engine oil, while the least was Staphylococcus aureus (8\%). Corynebacterium sp has also been reported by Onuoha et al. [22] with high emulsification ability among three hydrocarbon-degrading bacterial species isolated from soil.

Decrease in the $\mathrm{pH}$ of the medium (as shown on Table 5), increase in total viable counts (Table 6), as well as in turbidity of the medium (Table 7) were regarded as indicators of degradation. The correlation between the $\mathrm{pH}$ of the medium and cell growth with hydrocarbon utilization has been previously reported by Patila et al., [30]. The preliminary estimation of the isolate's degradative ability during growth in hydrocarbon supplemented medium suggested the effectiveness of growth in hydrocarbon medium by Corynebacterium kutscheri, and thus its potential as a candidate for further biodegradation studies.

\section{Conclusion}

The result of this study indicates that the contaminated environments possess indigenous populations within them, as seen in bacterial count results of microbiological growth of mineral salt cultures with waste engine oil as the sole carbon source. These indigenous bacteria isolated in this study show promising, ability to degrade petroleum hydrocarbons with Corynebacterium kutscheri as a potential candidate for further biodegradation efficiency studies.

\section{Acknowledgments}

The authors are grateful to the Laboratory Technologist of Microbiology Laboratory, Michael Okpara University, Umudike, Nigeria for their support.
1.Atlas RM. Oil spills: Regulation and Biotechnologyogy: guest editorial. Current Opinion in Biotechnology. 1995;3(3):220-223.

2.Bragg JR, Prince RC, Harner EJ, Atlas RM. Effectiveness of bioremediation for the Exxon Valdez oil spill. Nature. 1994 Mar;368(6470):413-8.

3.Uzoije AP, Agunwamba JC. Physiochemical properties of soil in relation to varying rates of crude oil pollution. International Journal of Environmental Science and Technology. 2011;4(3):313-23.

4.Benka-Coker MO, Ekundayo, JA. Effects of exposure of Arotherodon niloticus and Pariocephalus sp. to waste drilling fluid. Journal of Science Resource Development. 1995;23(4):122-125.

5.Ogundiran OO, Afolabi TA. Assessment of the physicochemical parameters and heavy metals toxicity of leachates from municipal solid waste open dumpsite. International Journal of Environmental Science and Technology. 2008 Mar 1;5(2):243-50.

6.Bossert I, Bartha R. The fate of petroleum in soil ecosystem. In: Petroleum microbiology. Atlas, R. M. (ed). New York:MacMillian;1984.p. 102-110.

7.Leahy JG, Colwell RR. Microbial degradation of hydrocarbons in the environment. Microbiology and Molecular Biology Reviews. 1990 Sep 1;54(3):305-15.

8.Saadoun I, Mohammad MJ, Hameed KM, Shawaqfah M. Microbial populations of crude oil spill polluted soils at the Jordan-Iraq desert (the Badia region). Brazilian Journal of Microbiology. 2008;39:453-456.

9.Prince R. The microbiology of marine oil spill bioremediation. In: Oliver B, Magot M, editors. Petroleum Microbiology, Washington: ASM Press; 2005.p.153-164.

10.Bamforth, SM, Singleton I. Bioremediation of polycyclic aromatic hydrocarbons: current knowledge and future directions. Journal of Chemistry, Technology and Biotechnology. 2005;80:723-736.

11.Vidali M. Bioremediation: An overview. Pure and Applied Chemistry. 2001;37(73):1163-1172.

12. Malatova K. Isolation and characterization of hydrocarbon degrading bacteria from environmental habitats in Western New York Stat. Department of Chemistry [Thesis]. New York: Rochester Institute of Technology, Rochester; 2005.p.76-88.

13.Prakash A, Bisht S, Singh J, Teotia P, Kela R, Kumar V. Biodegradation potential of petroleum hydrocarbons by bacteria and mixed bacterial consortium isolated from contaminated sites. Turkish Journal of Engineering and Environmental Science. 2014;38: 41-50.

14.Association of Official Analytical Chemists. Official methods of analysis of the Association of Analytical Chemists. Association of Official Analytical Chemists; 2003.

15.Association of Official Analytical Chemists. Official methods of analysis of the Association of Analytical

\section{References}


Chemists. Association of Official Analytical Chemists; 2005.

16.Chaîneau CH, Morel J, Dupont J, Bury E, Oudot J. Comparison of the fuel oil biodegradation potential of hydrocarbon-assimilating microorganisms isolated from a temperate agricultural soil. The Science of the Total Environmental. 2004;227:237-247.

17.Bremner JM, Mulvaney CS. Total nitrogen determination. In: Method of Soil Analysis, Page A L, Miller RH, Keeney DR, editors. Madison: American Society of Agronomy; 1982.p. 595-624.

18. Ogunbayo AO, Bello RA, Nwagbara U. Bioremediation of engine oil contaminated site. Journal of Emerging Trends in Engineering and Applied Science. 2012;3(3): 483-489.

19.Okpokwasili GC, Nwosu AI. Degradation of aldrine by bacterial isolates. Nigerian Journal of Technological Resources. 1990;2: 1-6.

20.Cheesbrough M. District Laboratory Practice in Tropical Countries. UK: Cambridge University Press. 1984;625 p.

21.Holt JG, Krieg NR, Sneath PHA, Staley JT, Williams ST. Bergey's Manual of Determinative Bacteriology. $9^{\text {th }}$ Edition. Baltimore: Williams and Williams Co.; 1994.

22. Onuoha SC, Olugbue VU, Uraku JA, Uchendu DO. Biodegradation potentials of hydrocarbon degraders from waste lubricating oil-spilled soils in Ebonyi State, Nigeria. International Journal of Agriculture and Biology. 2011;13: 586-590.

23.Ganesh A, Lin J. Diesel degradation and biosurfactant production by Gram-positive isolates. African Journal Biotechnology. 2009;8(21):5847-5854.

24.Chikere CB. Culture-independent analysis of bacterial community composition during bioremediation of crude oil-polluted soil. British Microbiological Resources Journal. 2012;2(3):187-211.

25.Chikere CB, Ekwuabu CB. Culture-dependent characterization of hydrocarbon utilizing bacteria in selected crude oil-impacted sites in Bodo, Ogoni land, Nigeria. African Journal of Environmental Science and Technology. 2014;8(6): 401-406.

26.Eze VC, Okpokwasili GC. Microbial and other related changes in Niger Delta River sediment receiving industrial effluents. Continental Journal of Microbiology. 2010;4:15-24.

27.Luepromchai E, Lertthamrongsak W, Pinphanichakarn P, Thaniyavarn S, Pattaragulwanit K, Juntongjin K. Biodegradation of PAHs in petroleum-contaminated soil using tamarind leaves as microbial inoculums. Biodegradation. 2007 Mar;29(2):516.

28. Banat IM, Makkar RS, Cameotra SS. Potential commercial applications of microbial surfactants. Applied Microbiology and Biotechnology. 2000;53(5): 495-508

29.Jennings EM, Tanner RS. Biosurfactant-producing bacteria found in contaminated and uncontaminated soils.
In: Proceedings of the Conference on Hazardous Waste Research, Oklahoma; 2000.299 p.

30.Patila TD, Pawara S, Kamblea PN, Thakare SB. Bioremediation of complex hydrocarbons using microbial consortium isolated from diesel oil polluted soil. Der Chemica Sinica. 2012;3(4):953-958.

31.Kaplan CW, Kitts CL. Bacterial succession in a petroleum land treatment unit. Applied Environmental Microbiology. 2004;70: 1777-1786 